\title{
Faktor yang Berhubungan dengan Kejadian Keracunan Pestisida Pada Petani Sayur dan Palawija di Desa Selat Kecamatan Pemayung Kabupaten Batang Hari Tahun 2018
}

\author{
Sondang Siahaan \\ Jurusan Kesehatan Lingkungan, Politeknik Kesehatan Kemenkes Jambi \\ Correspondence email: shn.sondang@gmail.com
}

\begin{abstract}
Abstrak. Pestisida adalah bahan beracun dan berbahaya, pestisida tersebut dapat menimbulkan dampak positif maupun negative bagi kesejahteraan manusia dan lingkungan. Dampak negative tersebut akan menimbulkan berbagai masalah baik secara langsung ataupun tidak langsung terhadap kesehatan. Keracunan pestisida dapat ditemukan dengan cara memeriksa aktifitas kholinesterase darah.Tujuan dari penelitian ini adalah untuk mengetahui faktor-faktor yang berhubungan dengan paparan pestisida terhadap kadar cholinesterase darah petani penyemprot tanaman palawija di Desa Selat Kecamatan Pemayung Kabupaten Batang Hari. Metode penelitian ini merupakan penelitian kuantitatif dengan rancangan Cross Sectional. Variabel Independen dalam penelitian ini adalah Pengetahuan tentang pestisida, Alat Pelindung Diri (APD), dan Penyemprotan dengan arah angin, sedangkan Variabel dependennya adalah Petani. Populasi adalah seluruh petani palawija di Desa Selat Kecamatan Pemayung Kabupaten Batang Hari dengan jumlah sampel berjumlah 30 orang. Dari hasil penelitian dengan menggunakan uji statistic maka ada hubungan tingkat Pengetahuan dengan keracunan pestisida dengan $p$-Value $=0,019$, Penggunaan Alat Pelindung Diri dengan $p$-Value $=0,024$ dan Penyemprotan dengan arah angin dengan nilai $\mathrm{p}$-Value $=0,000$. Kesimpulannya adalah petani Palawija di desa Selat yang mengalami keracunan sebesar 80,0 \%. Untuk menghindari keracunan pestisida, disarankan petani agar lebih meningkatkan pengetahuan tentang pestisida, pada saat penyemprotan harus memakai Alat Pelindung Diri (APD) yang lengkap dan benar, serta dalam melaksanakan penyemprotan agar memeperhatikan arah angin.
\end{abstract}

Kata kunci: Pengetahuan tentang Pestisida; Pakaian Pelindung; Arah Angin; Tingkat Cholinesterase

Abstract. Pesticide is toxic and harmful materials, this pesticide can cause either positive or negative impact for the prosperity of the human beings and environment. The negative impact wiil cause directly various problems to our health. Pesticide poisoning can be identified by examining blood cholinesterase activity. The aim of this research is to identify factors that related to pesticide exposure to the level of blood cholinesterase of farmers that spray non-staple food crops at Selat Village of Pemayung Sub-district of Batang Hari Ditrict. This research method is a quantitative research with cross sectional design. Independent variables in this research are knowledge concening pesticide, protective clothes, sprying in line with wind direction, while the dependent variable was the farmers. The population was all non-staple food crops farmers at at Selat Village of Pemayung Sub-district of Batang Hari Ditrict. The samples were 30 people. The results of the research by applying statistic test, there was a relation of knowledge to pesticide poisoning with $P$ value $=0.019$, the use of protective clothes with $P$ value $=0.024$ and spraying in line with wind direction with $P$ value $=0.000$. The research shows that non-staple food crops farmers at Selat Village had pesticide poisoning of $80.0 \%$. In order to prevent pesticide poisonong, it is recommended that the farmers should improve their knowledge regarding pesticide, while spraying the pesticide, farmers should wear complete protective clothes properly and make sure to follow the wind direction while spraying.

Keywords: Knowledge on Pesticide; Protective Clothes; Wind Direction; Cholinesterase Level

\section{PENDAHULUAN}

Tanaman Palawija memiliki peranan yang cukup penting dalam penyediaan kebutuhan pangan di Indonesia. Palawija adalah tanaman hasil kedua yang berarti tanaman pokok pangan hasil panen yang kedua setelah padi Hendratno (2016). Tanaman Palawija berfungsi untuk melakukan rotasi terhadap tanaman padi untuk memutuskan siklus dari gangguan hama tikus. Rotasi tersebut telah terbukti meningkatkan produktifitas hasil panen. Akan tetapi tanaman palawija ini sangat rentan terhadap gangguan serangan hama, untuk mengatasinya dibutuhkan banyak penggunaan pestisida yang merupakan salah satu upaya yang dilakukan para petani untuk mengatasi masalah tersebut.
Konsep pengendalian hama yang sejak semula banyak berdasarkan pada pengetahuan biologi dan ekologi semakin ditinggalkan dan diubah menjadi konsep pengendalian hama yang bertumpu pada penggunaan pestisida. Hal ini disebabkan karena penggunaan pestida lebih efektif dan efesien dalam mengendalikan hama di bandingkan dengan cara pengendalian sebelumnya.

Menurut Undang-Undang Nomor 12 (1992), Tentang sistem budidaya tanaman (Pasal 1) dalam Public Healt Home (2014), disebutkan bahwa pestisida adalah zat atau senyawa kimia atau zat perangsang tumbuh, bahan lain serta organisme renik, atau virus yang digunakan untuk melakukan perlindungan bagi tanaman. Penggunaan pestisida secara berlebihan dan terus 
menerus dapat menimbulkan berbagai gangguan pada lingkungan, ekosistem, dan kesehatan masyarakat. Afriyanto (2008) menyebutkan bahwa penggunaan pestisida dengan penyemprotan dapat menyebabkan gangguan kesehatan seperti keracunan pestisida, ngangguan sistem pernafasan, dan dapat menimbulkan kematian jika tidak segera diberikan pertolongan.

Menurut Kurniasih (2013), Pestisida merupakan racun yang mempunyai nilai ekonomi bagi petani. Diharapkan pestisida tersebut memiliki kemampuan membasmi organisme selektif (target organisme). Petani memiliki kedudukan ganda yang dikenal sebagai pelaku dan penderita keracunan pestisida, Sistem penggunaan yang tidak tepat sasaran dapat menimbulkan bahaya terhadap orang lain. Keracunan pestisida terjadi disebabkan oleh faktor kurangnya pengetahuan petani akan bahaya pestisida, masih banyaknya pestisida yang sangat berbahaya yang beredar dan mudah di dapat, dan tidak tersedianya alat pelindung diri yang aman, murah yang dapat digunakan petani.

Menurut Djojosumarto (2008), Petani Indonesia terutama yang berada di pedesaan masih banyak yang mengabaikan penggunaan pestisida sesuai anjuran, hanya 10 dari 1000 petani yang menerapkan pola penggunaan petisida sesuai anjuran. Penggunaan pestisida yang tidak sesuai dengan anjuran dapat menimbulkan paparan dalam tubuh seseorang. Paparan pestisida yang masuk ke dalam tubuh petani dapat menimbulkan tanda dan gejala yang dapat dirasakan oleh petani dan dapat di amati oleh orang lain, namun petani menganggap enteng gejala yang di timbulkan (Quijano dan Sarojeni, 1999).

Keracunan Pestisida dapat dilihat dari kadar cholinesterase dalam darah (Depkes RI, 1989), Berdasarkan data pada tahun 2011 di Desa Selat Kecamatan Pemayung dilakukan pemeriksaan 50 orang petani sayur dengan hasil petani yang menderita keracunan sebanyak $72 \%$ (laporan Tahunan seksi penyehatan Dinas Kesehatan Kabupaten Batang Hari). Dari data yang ada, maka diketahui bahwa petani sayur tersebut mempunyai resiko terpapar nya yang tinggi. Upaya mencegah terjadinya keracunan pestisida yang bisa mengakibatkan kematian maka perlu diketahui penyebab terjadinya paparan pestida tersebut.

\section{METODE \\ Desain Penelitian}

Penelitian ini merupakan penelitian kuantitatif dengan pendekatan cross sectional. Penelitian ini menjelaskan hubungan antara pengetahuan tentang pestisida, APD, dan penyemprotan dengan arah angin dengan keracunan pestisida pada petani palawija di Desa Selat Kecamatan Pemayung Kabupaten Batang Hari tahun 2019.

\section{Waktu dan Lokasi Penelitian}

Penelitian dilakukan di Desa Selat Kecamatan Pemayung Kabupaten Batang Hari, waktu penelitian selama 12 (duabelas) minggu pada bulan Januari Sampai dengan Juli 2019.

\section{Populasi dan Sampel \\ Populasi}

Dalam penelitin ini yang menjadi populasi adalah seluruh petani palawija yang berada di Desa Selat Kecamatan Pemayung Kabupaten Batang Hari.

\section{Sampel}

Sampel dalam peneltian ini adalah dengan menggunakan teknik Purposive sampling yaitu teknik pengambilan sampel pada pertimbangan tertentu yang dibuat oleh peneliti sendiri berdasarkan ciri atau sifatsifat populasi yang sudah diketahui sebelumnya. Berdasarkan kriteria tersebut Jumlah sampel sebanyak 60 orang.

Agar karakteristik tidak menyimpang maka pengambilan sampel dilakukan dengan kriteria inklusi yaitu kriteria yang dipenuhi oleh semua anggota populasi, dengan kriteria inklusi sebagai berikut:

1. Melakukan penyemprotan tidak kurang dari 1 minggu

2. Tidak dalam masa penyembuhan atau sakit yang berhubungan dengan hati, seperti hepatitis dan serosis.

3. Bersedia menjadi resonden.

\section{Pengumpulan Data \\ Data Primer}

Data primer yaitu data yang dikumpulkan melalui wawancara langsung terhadap responden menggunakan kuisioner yang ditujukan kepada petani palawija yang akan diperiksa kadar cholinesterase darahnya dengan menggunakan alat Tintometer kit Lovibond.

\section{Data Sekunder}

Data sekunder yaitu data topografi, demografi, dan monografi wilayah Desa Selat Kecamatan Pemayung Kabupaten Batang Hari.

\section{Instrumen Penelitian}

Instrumen penelitian adalah alat -alat yang digunakan untuk pengumpulan data. Instrumen yang dipakai dalam penelitian ini sebagai berikut:

\section{Tintometer kit Lovibond}

Digunakan untuk mengukur tingkat paparan pestisida (kadar cholinesterase darah petani. Pengukuran dilakukan dengan pengambilan sampel darah pada ujung jari.

\section{a. Prinsip Pengujian}

Darah yang berisi enzim cholinesterase membebaskan acetyc acid (asam asetat) dari acetyl 
cholin karena itu akan merubah $\mathrm{pH}$. Suatu campuran yang terdiri darah, indikator dan acetyl cholin perchorat disiapkan dan didiamkan untuk bebebrapa saat tertentu. Perubahan $\mathrm{pH}$ selama periode ini diukur dengan membandingkan warna permanen yang dipasang pada disk. Perubahan $\mathrm{pH}$ adalah ukuran dari tingkat aktifitas cholinesterase darah.

\section{b. Bahan dan Alat}

Bahan - bahan yang digunakan dalam pemeriksaan kadar cholinesterase darah terdiri dari : Brom Timol Blue (BTB), 112 gr (sebagai larutan indikator), aquades (bebas CO2) $250 \mathrm{ml}$ dan Acetylcholine Perchlorat (ACP) 0,25 gr. Alat yang digunakan adalah cholinestesterase tes kit (Tintometer Kit Lovibond 2000), Erlenmeyer, Tabung reaksi, botol reagen, kuvet, pipet, dll).

c. Menyiapkan Aquades bebas $\mathrm{CO2}$

Didihkan aquades sampai keluar gelembunggelembung selama kira-kira 10 menit. Erlenmeyer tempat aquades ditutup dengan kapas, didinginkan atur $\mathrm{pH}$ hingga 6 .

\section{d. Membersihkan alat-alat :}

Memanaskan prop karet 2 kali atau sampai air bilasan pH 6, dan Membersihkan alat-alat gelas maupun polyethilen dengan menggunakan aquades bebas $\mathrm{CO} 2$ sebanyak 3 kali.

\section{e. Membuat Larutan Reagen}

1) Membuat Larutan Indicatore

Larutan terdiri dari BTB (Brom Timol Blue) 112 mg dan aquades bebas $\mathrm{CO} 2$ atau aquadestilata 250 $\mathrm{ml}$.

2) Membuat Larutan substrat

Larutan ini terdiri dari acetilcholineperclorat (ACP) 0,25 gr dan aqua bebas CO2 (aquadestilata) $50 \mathrm{ml}$.

3) Menyiapkan aquades bebas $\mathrm{CO} 2$ yang segar sebanyak $60 \mathrm{ml}$ pada botol berlabel desttiled water kemudian segera ditutup dengan stopernya.

4) Membuat blood blank ( blangko darah )

5) Test Reagen

6) Penentuan cholinesterase darah

7) Siapkan tabung-tabung reaksi bulat dengan sumbat karetnya sejumlah orang yang diperiksa, selanjutnya tempatkan tabung-tabung tersebut pada rak yang tersedia.

8) Ambil dengan pipet $0,5 \mathrm{cc}$ larutan indicator dan masukan ke dalam seluruh tabung reaksi yang telah disiapkan dan segera tutup kembali.

9) Ambil sampel darah sebanyak 0,01 cc dari tiap orang yang akan di uji dan masukan sampel darah tersebut ke dalam masing-masing tabung secara berurutan sesuai dengan urutan nama dalam daftar nama yang tersedia. Setiap pengambilan sampel darah, gunakan tip yang baru agar tidak terjadi kontaminasi.
10) Mulailah dari tabung untukresponden pertama, tambahkan larutan subtrat 0,5 cc kedalamnya dengan selang waktu 1 menit. Catat waktu masuknya dan baca hasilnya pada saat waktu selesai, demikian seterusnya.

\section{f. Pengambilan Sampel Darah}

Syarat-syarat:

1) Jari yang boleh ditusuk adalah salah satu diantara jari telunjuk, jari tengah dan jari manis.

2) Daerah pada ujung jari yang akan ditusuk harus dicuci dengan bersih, kering dan telah diolesi alkohol agar bebas kuman.

3) Selanjutnya jari ditusuk dengan pensteril

\section{g. Penentuan Cholinesterase darah}

1) Tabung reaksi yang akan digunakan disesuaikan dengan jumlah orang yang akan diambil darahnya.

2) Tabung pertama diisi aquades bebas $\mathrm{CO} 2$ Sebanyak $1 \mathrm{cc}$ Tabung kedua diisi larutan BTB $0,5 \mathrm{cc}$

3) Temperatur catat saat pemeriksaan pada kartu pencatat hasil yang telah disiapkan. Siapkan juga tabel time out yang dibutuhkan.

\section{h. Analisa Hasil}

Dengan ketentuan hasil sebagai berikut:

1) Normal bila hasilnya $75 \%-100 \%$

2) Keracunan bila hasinya $<75 \%$

\section{Kuisioner}

Instrumen kuisioner digunakan untuk memperoleh data dari responden (nama, umur, masa kerja, jenis kelamin, pendidikan, pengetahuan tentang pestisida, alat pelindung diri dan penyemprotan dengan arah angin).
Pengolahan Data
a. Editing
b. Coding
c. Entry Data
d. Cleaning Data ( Pembersihan Data )

\section{Analisa Data \\ Analisa Deskriptif}

Analisa univariat bertujuan untuk gambaran distribusi frekuensi dan proporsi dari setiap variabel penelitian, baik variabel bebas (Pengetahuan tentang pestisida, Alat pelindung diri dan penyemprotan dengan arah angin) maupun terikat (kadar cholinesterase).

\section{Analisa Inferensial}

Analisa ini dilakukan terhadap dua variabel yaitu variabel indipenden dengan yang dependen yang di duga berhubungan atau berkorelasi dengan menggunakan chi square, dan untuk melihat hasil kemaknaan perhitungan statistik digunakan batas kemaknaan 5\% $(0,05)$. 


\section{HASIL PENELITIAN \\ Analisis Univariat}

Analisis Univariat digunakan untuk melihat distribusi frekuensi dari semua variable independen dan variable devenden. Variabel indipenden terdiri dari pengetahuan, alat pelindung diri, penyemprotan dengan arah angin. Sedangkan Variabel dependennya adalah hasil tes cholinesterase pada Petani. Berikut adalah karakteristik responden yang meliputi:

\section{Umur}

Dari pengumpulan data umur petani palawija di Desa Selat Kabupaten Batang Hari tahun 2019 dapat dilihat pada table berikut:

Tabel 1. Distribusi Frekuensi Umur Petani Palawija di Desa Selat Kecamatan Pemayung Kabupaten Batang Hari Tahun 2019

\begin{tabular}{clll}
\hline No & \multicolumn{1}{c}{ Umur } & \multicolumn{1}{c}{ Jumlah } & Persentase \\
\hline 1 & $\leq 30$ tahun & 4 & $13,3 \%$ \\
2 & $31-45$ tahun & 12 & $40,0 \%$ \\
3 & $>45$ tahun & 14 & $46,7 \%$ \\
\hline
\end{tabular}

Sumber: Data diolah

Berdasarkan table di atas diketahui bahwa umur petani yang paling banyak adalah lebih dari 45 tahun sebanyak 14 orang $(46,7 \%)$, dan yang paling sedikit berumur $\leq 30$ tahun sebanyak 4 orang $(13,3 \%)$.

\section{Masa kerja}

Masa kerja petani palawija di Desa Selat dapat dilihat pada table di bawah ini:

Tabel 2. Distribusi Frekuensi Masa Kerja Petani Palawija di Desa Selat Kabupaten Batang Hari Tahun 2019

\begin{tabular}{clll}
\hline No & \multicolumn{1}{c}{ Masa Kerja } & \multicolumn{1}{c}{ Jumlah } & Persentase \\
\hline 1 & $\leq 10$ tahun & 27 & $90,0 \%$ \\
2 & $>10$ tahun & 3 & $10,0 \%$ \\
\hline
\end{tabular}

Sumber: Data diolah

Dari tabel diatas dapat dilihat bahwa masa kerja sebagai petani palawija di Desa Selat Kabupaten Batang Hari yang kurang dari atau sama dengan 10 tahun sebanyak 27 orang $(90,0 \%)$ dan lebih dari 10 tahun sebanyak 3 orang $(10,0 \%)$.

\section{Pengetahuan tentang Pestisida}

Pengetahuan responden terhadap pestisida dapat dilihat pada tabel berikut:

Tabel 3. Distribusi Frekuensi Menurut Pengetahuan Tentang Pestisida Petani Palawija di Desa Selat Kabupaten Batang Hari Tahun 2019

\begin{tabular}{cccc}
\hline No & $\begin{array}{c}\text { Pengetahuan tentang } \\
\text { Pestisida }\end{array}$ & Jumlah & Persentase \\
\hline 1 & Tinggi & 16 & $53,3 \%$ \\
2 & Rendah & 14 & $46,7 \%$ \\
\hline
\end{tabular}

Berdasarkan tabel diatas dapat diketahui bahwa 16 orang $(53,3 \%)$ mempunyai tingkat pengetahuan yang tinggi dan 14 orang $(46,7 \%)$ mempunyai tingkat pengetahuan rendah tentang pestisida.

\section{Alat Pelindung Diri (APD)}

Alat Pelindung Diri (APD) yang digunakan petani dapat dilihat pada table berikut:

Tabel 4. Distribusi Frekuensi Menurut Alat Pelindung Diri petani Ayur dan Palawija di Desa Selat Kecamatan Pemayung Kabupaten Batang Hari Tahun 2019

\begin{tabular}{clcc}
\hline No & Penggunaan APD & Jumlah & Persentase \\
\hline 1 & Memenuhi syarat & 17 & $56,7 \%$ \\
2 & Tidak memenuhi syarat & 13 & $43,3 \%$ \\
\hline
\end{tabular}

Sumber: Data diolah

Berdasarkan tabel diatas dapat dilihat bahwa petani yang menggunakan APD memenuhi syarat sebanyak 17 orang $(56,7 \%)$ dan yang tidak memenuhi syarat sebanyak 13 orang $(43,3 \%)$.

\section{Penyemprotan Dengan Arah Angin}

Penyemprotan dengan arah angin dapat dilihat pada tabel dibawah:

Tabel 5. Distribusi Frekuensi Menurut Penyemprotan dengan Arah Angin Petani Sayur dan Palawija di Desa Selat Kecamatan Pemayung Kabupaten Batang Hari Tahun 2019

\begin{tabular}{clcc} 
No & $\begin{array}{c}\text { Penyemprotan Dengan } \\
\text { Arah Angin }\end{array}$ & Jumlah & Persentase \\
\hline 1 & Ya & 6 & $20,0 \%$ \\
2 & Tidak & 24 & $80,0 \%$ \\
\hline
\end{tabular}

Sumber: Data diolah

Dari tabel di atas menunjukan bahwa petani yang memperhatikan arah angin saat menyemprot sebanyak 6 orang $(20,0 \%)$ dan petani yang tidak memperhatikan arah angin saat menyemprot sebanyak 24 orang $(80,0 \%)$.

\section{Kejadian Keracunan Pestisida}

Hasil pemeriksaan kadar cholinesterase dapat dilihat pada tabel berikut ini:

Tabel 6. Distribusi Frekuensi Menurut Keracunan Pestisida Petani Sayur dan Palawija di Desa Selat Kecamatan Pemayung Kabupaten Batang Hari Tahun 2019

\begin{tabular}{clcc}
\hline No & Kadar Cholinesterase & Jumlah & Persentase \\
\hline 1 & Normal & 6 & $20,0 \%$ \\
2 & Keracunan & 24 & $80,0 \%$ \\
\hline
\end{tabular}

Sumber: Data diolah

Dari tabel diatas menunjukan bahwa hasil pemeriksaan cholinesterase dalam darah petani yang normal sebanyak 6 orang $(20,0 \%)$ dan yang keracunan sebanyak 24 orang $(80,0 \%)$. 
Sondang Siahaan, Faktor yang Berhubungan dengan Kejadian Keracunan Pestisida Pada Petani Sayur dan Palawija di Desa Selat Kecamatan Pemayung Kabupaten Batang Hari Tahun 2018

\section{Analisis Bivariat}

Untuk mengetahui apakah variable independen berhubungan dengan variable dependen, maka dilakukan

\section{Hubungan Tingkat Pengetahuan Dengan Keracunan Pestisida} analisa hubungan dengan menggunakan uji statistic $C h i$ Square dengan hasil sebagai berikut:

Tabel 7. Hubungan Pengetahuan tentang Pestisida dengan Keracunan Pestisida Petani Sayur dan Palawija di Desa Selat Kabupaten Batang Hari

\begin{tabular}{|c|c|c|c|c|c|c|}
\hline \multirow{2}{*}{ Pengetahuan } & \multicolumn{4}{|c|}{ Kadar Cholinesterase } & \multirow{2}{*}{ Total } & \multirow{2}{*}{$\mathrm{P}$ - value } \\
\hline & Normal & $\%$ & Keracunan & $\%$ & & \\
\hline Tinggi & 6 & $37,5 \%$ & 10 & $62,5 \%$ & 16 & 0,019 \\
\hline Rendah & 0 & $0 \%$ & 14 & $100 \%$ & 14 & \\
\hline Jumlah & 6 & $20,0 \%$ & 24 & $80 \%$ & 30 & \\
\hline
\end{tabular}

Sumber: Data diolah

Tabel diatas menunjukan bahwa dari 14 petani yang mempunyai pengetahuan rendah, sebanyak 14 orang ( $100 \%)$ mengalami keracunan, sedangkan petani yang mempunyai pengetahuan tentang pestisida tinggi sebanyak 16 orang mengalami keracunan pestisida sebanyak 10 orang $(62,5 \%)$. Berdasarkan uji chi - square diperoleh nilai $\mathrm{p}$-value $=0,019(\mathrm{p}<0,05)$ menunjukan ada hubungan antara pengetahuan responden dengan kadar cholinesterase.

\section{Hubungan Penggunaan Alat Pelindung Diri (APD) dengan Kadar Cholinesterase}

Tabel 8. Hubungan Alat Pelindung Diri dengan Keracunan Pestisida Petani Palawija di Desa Selat Kecamatan Pemayung Kabupaten Batang Hari

\begin{tabular}{lcccccc}
\hline \multirow{2}{*}{ Alat Pelindung Diri } & \multicolumn{3}{c}{ Hasil Pemeriksaan Cholinesterase } & Total & P-value \\
\cline { 2 - 5 } & Normal & $\%$ & Keracunan & $\%$ & 17 & 0,024 \\
\hline Memenuhi syarat & 6 & $35,3 \%$ & 11 & $64,7 \%$ & 13 & \\
Tidak memenuhi syarat & 0 & $0 \%$ & 13 & $100 \%$ & 30 & \\
Jumlah & 6 & $20 \%$ & 24 & $80 \%$ & \\
\hline
\end{tabular}

Sumber: Data diolah

Tabel diatas diketahui petani yang tidak memenuhi syarat dalam memakai alat pelindung diri yaitu sebanyak 13 orang dengan angka keracunan sebanyak 13 orang (100\%). Sedangkan petani yang memakai alat pelindung diri memenuhi syarat sebanyak 17 orang yang mengalami keracunan 11 orang $(64,7 \%)$.
Berdasarkan uji Chi square diperoleh nilai $\mathrm{p}$ Value $=0,024,(\mathrm{p}<0,005)$ maka ada hubungan antara penggunaan alat pelindung diri dengan kadar cholinesterase.

\section{Hubungan Penyemprotan dengan Arah Angin dengan Kadar Cholinesterase}

Tabel 9. Hubungan Penyemprotan Dengan Arah Angin dengan Keracunan Pestisida Petani Palawija di Desa Selat Kecamatan Pemayung Kabupaten Batang Hari

\begin{tabular}{|c|c|c|c|c|c|c|}
\hline \multirow{2}{*}{$\begin{array}{c}\text { Penyemprotan Dengan Arah } \\
\text { Angin }\end{array}$} & \multicolumn{4}{|c|}{ Kondisi Keracunan } & \multirow[t]{2}{*}{ Total } & \multirow[t]{2}{*}{$\mathrm{P}$ - value } \\
\hline & Normal & $\%$ & Keracunan & $\%$ & & \\
\hline Memperhatikan & 6 & $100 \%$ & 0 & $0 \%$ & 6 & 0,000 \\
\hline Tidak memperhatikan & 0 & $0 \%$ & 24 & $100 \%$ & 24 & \\
\hline Jumlah & 6 & $20 \%$ & 24 & $80 \%$ & 30 & \\
\hline
\end{tabular}

Sumber: Data diolah

Dari tabel diatas diketahui petani yang memperhatikan arah angin yaitu sebanyak 6 orang dan tidak ada yang mengalami keracunan. Dan petani yang tidak memperhatikan arah angin waktu penyemprotan pestisida sebanyak 24 orang dan mengalami keracunan sebanyak 24 (100\%). Berdasarkan hasil tersebut diatas dapat diketahui pula bahwa angka keracunan pestisida tertinggi pada petani yang tidak mau memperhatikan arah angin pada saat penyemprotan.

\section{Pembahasan}

\section{Hubungan Pengetahuan Tentang Pestisida dengan Keracunan Pestisida}

Pengetahuan seseorang biasanya diperoleh dari pengalaman berbagai macam sumber, misalnya media masa, media elektronik, buku petunjuk, petugas kesehatan, label, dan kerabat dekat. Pengetahuan seseorang terhadap objek mempunyai intensitas atau tingkatan yang berbeda-beda. Sesuai dengan teori Lawrence Green (1980) yang mengatakan bahwa 
pengetahuan tidak berkaitan langsung dengan status kesehatan, akan tetapi harus melalui sikap atau praktek. Pengetahuan akan mempengaruhi sikap seseorang untuk bertindak. Pengetahuan merupakan domain yang sangat penting untuk terbentuknya praktek seseorang. Responden yang pengetahuannya relatif tidak baik tentang pestisida mencerminkan adanya ketidak pedulian terhadap kesehatan, baik bagi dirinya ataupun lingkungannya.

Dari hasil penelitian diketahui bahwa 16 orang $(53,3 \%)$ mempunyai tingkat pengetahuan tinggi dan sebanyak 14 orang ( $46,7 \%)$ mempunyai tingkat pengetahuan rendah tentang pestisida.

Dari 16 orang yang mempunyai pengetahuan tinggi, sebanyak 10 orang $(62,5 \%)$ mengalami keracunan dan hanya 6 orang ( $37,5 \%$ ) yang tidak mengalami keracunan. Sedangkan petani yang yang mempunyai pengatahuan tentang pestisida rendah sebanyak 14 orang yang mengalami keracunan sebanyak 14 orang (100\%).

Berdasarkan uji chi square diperoleh nilai $\mathrm{p}-\mathrm{V}$ alue $=0,019(\mathrm{p}<0,05)$ menunjukan ada hubungan antara pengetahuan responden dengan kadar cholinesterase.

Berdasarkan hasil wawancara terhadap petani, maka petani cenderung menggunakan pestisida berdasarkan pengalaman yang pernah dialami, dan tidak mentaati aturan yang sudah diberikan pada saat pelatihan. Di dalam quisioner tentang pengetahuan ternyata pada pertanyaan nomor 8 dari total 30 orang $(100 \%)$ responden, hanya 7 orang $(23,3 \%)$ yang menerapkan penggunaan APD, dan sisanya sebanyak 23 orang $(76,6 \%)$ tidak menggunakan APD sesuai dengan aturan yang berlaku. Sehingga dapat dikatakan bahwa mereka yang sudah mempunyai pengetahuan tinggi belum tentu tidak mengalami keracunan.

Upaya yang harus dilakukan oleh instansi terkait seperti Dinas Kesehatan, Dinas Pertanian, Dinas Perkebunan adalah melakukan penyuluhan tentang bagaimana penanganan pestisida yang tepat dan aman serta bahaya-bahaya apa yang dapat ditimbulkan oleh pestisida. Dengan metode simulasi praktek penanganan menggunakan pendekatan pemberdayaan masyarakat.

Penekanan materi penyuluhan meliputi: Pengetahuan tentang pengertian pestisida dan dampak negatifnya, cara pestisida masuk kedalam tubuh, gejala dan tanda-tanda keracunan pestisida, tindakan/pertolongan yang harus dilakukan bila terjadi keracunan pestisida, dan cara membersihkan peralatan yang digunakan setelah menyemprot.

\section{Hubungan Penggunaan Alat Pelindung Diri (APD) dengan Keracunan Pestisida}

Menurut Djojosumarto (2008) untuk melindungi badan dari pemaparan pestisida dapat digunakan pelindung diri berupa: pakaian kerja (Body covering) yang baik adalah menggunakan pakaian terusan (workpark), masker, sarung tangan (gloves) yang berfungsi baik hendaknya harus panjang sehingga menutupi pergelangan tangan. Topi (hat) terbuat dari bahan yang kedap cairan dan sedapat mungkin melindungi bagian-bagian kepala, sepatu bot (boot), kacamata yang dapat melindungi mata dari percikan (partikel-partikel) pestisida.

Dari hasil penelitian petani yang menggunakan APD yang memenuhi syarat sebanyak 17 orang $(56,7 \%)$ dan yang tidak memenuhi syarat sebanyak 13 orang $(43,3 \%)$. Dari petani yang memenuhi syarat memakai APD sebanyak 17 orang yang mengalami keracunan sebanyak 11 orang $(64,7 \%)$ dan yang normal sebanyak 6 orang $(35,3 \%)$, sedangkan petani yang tidak memenuhi syarat memakai APD sebanyak 13 orang yang mengalami keracunan sebanyak 13 orang (100\%).

Berdasarkan uji Chi square diperoleh nilai $\mathrm{p}$ Value $=0,024(\mathrm{p}<0,05)$ maka ada hubungan antara penggunaan alat pelindung diri dengan kadar cholinesterase.

Dari hasil observasi dan wawancara langsung masih banyaknya petani yang terpapar pestisida walaupun telah menggunakan beberapa alat pelindung diri seperti baju tangan panjang, sepatu bot, topi, ini dikarenakan alat pelindung diri yang mereka gunakan tidak memenuhi syarat dan asal-asalan, serta dengan alasan sesak dan tidak nyaman bila dipakai pada waktu menyemprot.

Dari hasil quisioner ternyata pada pertanyaan II Romawi tentang APD , petani yang menggunakan APD yang memenuhi syarat sebanyak 17 orang $(56,7 \%)$ ternyata hanya 6 orang $(35,3 \%)$ yang memakai APD lengkap dan benar, sedangkan sisanya 11 orang $(64,7 \%)$ tidak memakai APD lengkap dan benar.

Kepada petani pengguna pestisida disarankan agar memakai alat pelindung diri secara lengkap dan benar serta memenuhi syarat. Pemakaian alat pelindung diri secara lengkap, baik, benar dan memenuhi syarat akan terhindar dari paparan pestisida dan penggunaan alat pelindung diri merupakan pencerminan langsung pengetahuan petani terhadap kemungkinan pemaparan pestisida dan melakukan praktek pelaksanaannya pada waktu menyemprot. Selain itu juga petani agar tidak berperilaku merokok atau makan pada waktu menyemprot dan mengelap keringat dengan lengan baju pada saat melakukan penyemprotan.

\section{Hubungan Penyemprotan dengan Arah Angin dengan Keracunan Pestisida}

Tindakan penyemprotan pada arah angin adalah tindakan petani saat menyemprot tanaman dengan pestisida terhadap arah angin. Penyemprotan yang baik harus searah dengan angin dan sebaiknya penyemprotan tidak dilakukan apabila angin sedang bertiup kencang.

Dari hasil penelitian menunjukan bahwa petani yang tidak memperhatikan arah angin waktu 
penyemprotan sebanyak 24 orang $(80,0 \%)$ dan yang memperhatikan arah angin sebanyak 6 orang $(20,0 \%)$.

Dari petani yang tidak memeperhatikan arah angin sebanyak 24 orang, yang mengalami keracunan sebanyak 24 orang (100\%), sedangkan yang memperhatikan arah angin sebanyak 6 orang yang normalnya sebanyak 6 orang (100\%). Berdasarkan hasil tersebut dapat diketahui pula bahwa angka keracunan pestisida tertinggi terjadi pada petani yang tidak memeperhatikan arah angin pada saat menyemprotan sebanyak 24 orang $(80 \%)$.

Berdasarkan uji statistic dengan uji chi square diperoleh nilai $\mathrm{p}$-Value $=0,000(\mathrm{p}<0,05)$ maka ada hubungan antara arah angin dengan kadar cholinesterase. Hasil pengujian statistik pada penelitian ini menunjukan bahwa petani yang tidak memperhatikan arah angin saat melakukan penyemprotan akan mempunyai resiko terjadinya keracunan pestisida disbanding dengan petani yang menyemprot mengikuti arah angin.

\section{SIMPULAN}

Berdasarkan analisa dan pembahasan hasil penelitian yang telah dilakukan pada petani palawija di Desa Selat Kecamatan Pemayung Kabupaten Batang Hari dapat disimpulkan bahwa:

1. Hasil pemeriksaan Kadar Cholinesterase darah petani palawija di Desa Selat Kecamatan Pemayung Kabupaten Batang Hari yang mengalami keracunan sebesar $80,0 \%$ atau 24 orang dari 30 petani yang diperiksa.

2. Ada hubungan tingkat pengetahuan dengan keracunan pestisida pada petani palawija di desa Selat Kecamatan Pemayung Kabupaten Batang Hari adalah $\mathrm{p}-$ Value $=0,019$

3. Ada hubungan penggunaan Alat Pelindung Diri (APD) dengan keracunan pestisida pada petani palawija di desa Selat dengan $\mathrm{p}$-Value $=0,024$.

4. Ada hubungan teknik penyemprotan dan arah angin dengan keracunan pestisida pada petani palawija di Desa Selat Kecamatan Pemayung dengan nilai pValue $=0,000$.

\section{DAFTAR PUSTAKA}

Afriyanto. 2008. Kajian Keracunan Pestisida Pada Petani Penyemprot Cabe di Desa Candi Kecamatan Bandungan Kabupaten Semarang. Thesis. Universitas Diponegoro Semarang.

Anonim. 2014. Cholinesterase dan Mekanisme Keracunan Pestisida. Public Healt Home. Kesehatan Masyarakat.

Djojosumarto, 2008. Pestisida \& Aplikasinya, Pt. Agromedia Pustaka. Jakarta.

Depkes RI, 1989. Pemeriksaan cholinesterase darah dengan Tintometer, Ditjen PPM \& PLP, Jakarta
Green, Lawrence, 1980. Health Education: A Diagnosis Approach, The John Hopkins University, Mayfield Publishing Co.

Hendratno. 2016. Pengertian, Manfaat dan Jenis - Jenis Tanaman Palawija yang perlu diketahui.

Kurniasih, SA. 2013. Faktor Resiko Terhadap Paparan Pestisida di Lingkungan Pertanian dengan Pendekatan Epidemiologi. http: // www: media.neliti.com > publication. Diakses tanggal 03 Maret 2018. Jurnal kesehatan Lingkungan Indonesia. Volume 12. No.2

Quijano. Sarojeni. 1999. Awas Pestisida Berbahaya Bagi Kesehatan. Terjemahan oleh Ronald M, Yayasan Duta Awam. Solo. 